\title{
DEVELOPMENT OF THE DISEASE MODEL OF DRUG ADDICTION IN BRITAIN, 1870-1926
}

\author{
by \\ TERRY M. PARSSINEN and KAREN KERNER*
}

\section{SUMMARY}

OPIUM WAS widely used in the nineteenth century as an analgesic, a febrifuge, a sedative, and an anti-diarrhoea agent. Opium's addictive properties had been noted in the medical literature as early as 1700 , but medical men did not take these very seriously. With the advent of the hypodermic syringe in 1856 , which made it possible for morphia (the alkaloid of opium) to be injected, physicians became increasingly concerned about addiction. From 1878, they began to discuss the "disease" of drug addiction. What had begun as a trickle in the medical literature eventually became a torrent and, by 1910, a fully mature disease model of drug addiction had been developed. This had an enormous influence on both the popular understanding and national policies toward drug addiction in the period between 1910 and 1930. The reasons why medical men characterized drug addiction as a disease derived from specific features of the "culture of medicine" in the late nineteenth century: the concept of disease, the social role and status of the medical profession, the perception of public health concerns, and the political goals and influence of medical men. Considered within the context of the historiography of medicine, the development of the concept of drug addiction can illuminate how traditional and radical perspectives can be combined to produce a richer understanding of medical history.

We intend to show how the disease model of drug addiction came to prominence in Britain in the late nineteenth century, and how this affected both popular understanding and national policy toward the issue.

I have myself been in the habit of taking morphia for thirty years. I began by taking chlorodyne for a spasmodic complaint, as ordered by two eminent medical men. It was changed by my husband for morphia, with the result that by constantly increasing the dose it came at last to 4 scruples per week, which has been the regular quantity taken now for very many years.

This medicine - so deleterious in most instances - has by no means impaired the vitality of my system, or tended in any degree to reduce my activity, which is equal to that of many young women, although I am now 67 years of age.

My enjoyment of life is perfect, and I have none of the haggard, emaciated look borne by most persons who adopt this treatment. My eyes are black and bright, the sight being no worse than that of most persons my age.

The only evil which appears to arise from the use of this medicine is a considerable increase of fat, and I should be considerably obliged if any of your contributors will kindly inform me if this increase of adipose tissue is a natural result of the morphia.

I am, sir, yours faithfully,

E.L.P.B. 1

* Senior research fellows, Institute for the Study of Human Issues, 3401 Market Street, Philadelphia, Pa. 19104, USA. The authors wish to express their gratitude for the considerable assistance they have received from their colleagues at ISHI, Elaine Berman, David Feingold, and Carol Parssinen, and from Professor David Courtwright of the University of Hartford. The research was supported by grant no. DA01656 from the National Institute on Drug Abuse.

1 Chemist Drugg. , 3 March 1888, 32: 297-298. 


\section{Terry M. Parssinen and Karen Kerner}

This letter was written by a chemist's wife, and published in the national trade journal, Chemist and Druggist, in 1888. It is interesting, both because of what it says directly about one woman's drug habit, and also because of what it says indirectly about the social perception of morphia habituation.

A respectable, elderly lady has a morphia habit of long duration. She has no hesitation about admitting it in print, and her only regret is that she fears the morphia is making her fat. Yet she is sufficiently aware of the contemporary professional literature on morphia-takers to consider herself something of an exception. Most habitual morphia-takers, she believes, suffer from deleterious side effects which, for some reason, do not seem to trouble her. But what is most striking about the letter is the lack of moralizing about her circumstances. She obviously does not regard herself as a social pariah, enslaved to an immoral vice, nor does the tone of the letter suggest that she is challenging such a social stereotype. She is not a dope fiend, but a gentlewoman, who has slipped into a relatively harmless habit in the course of medical treatment. Her self-image, which was presumably shared by her readers, reflected the dominant perception of drug habituation in mid-Victorian Britain. But in 1888, when the letter was published, a change was already under way, a change which we see presaged, perhaps, in the edgy, slightly defensive tone of the lady's self-description. Thanks largely to the work of German physicians in the previous decade, British medical men, by the 1880 s, were beginning to discuss the disease of drug addiction.

\section{MEDICAL LITERATURE ON OPIUM AND MORPHINE THROUGH THE EARLY 1870S}

Until the revolution in therapeutics in the early twentieth century, physicians did not so much cure diseases as manage their symptoms. Given this fundamental limitation in nineteenth-century medical practice, opium was invaluable. Jonathan Pereira, in his influential textbook on materia medica and therapeutics, claimed that "opium is undoubtedly the most important and valuable remedy of the whole Materia Medica. We have, for other medicines, one or more substitutes; but for opium we have none. . . . Its good effects are not, as is the case with some valuable medicines, remote and contingent, but they are immediate, direct, and obvious; and its operation is not attended with pain or discomfort." 2 Opium had a wide variety of uses, most notably as an analgesic, a febrifuge, a sedative, and as a specific for gastro-intestinal difficulty, especially diarrhoea. It was taken in powder, pills, or in liquid, most commonly as laudanum - tincture of opium. Opium was also the main ingredient in several of the more infamous Victorian popular and proprietary medicines, most notably "Lancaster Black Drop", "Battley's Syrup", Dr. J. Collis Browne's "Chlorodyne", and "Godfrey's Cordial".

Morphia, the alkaloid derivative of opium, was isolated in the early nineteenth century, and was commercially available from the $1820 \mathrm{~s}$. But as long as it had to be taken orally, there was little to recommend it over opium. Morphia did not come into widespread use until the 1860 s, a few years after Dr. Alexander Wood perfected the hypodermic syringe, which made possible an entirely new mode of administering

2 Jonathan Pereira, The elements of materia medica and therapeutics, Philadelphia, Lea \& Blanchard, 1843, vol. 2, p. 703. 


\section{Development of the disease model of drug addiction in Britain, 1870-1926}

medication. Wood and Dr. Charles Hunter publicized the use of hypodermic injections of morphia for the relief of neuralgia. Wood's paper of 1858 , delivered before the British Medical Association, and then published in the British Medical Journal, was particularly important in making ordinary practitioners aware of the new therapy. ${ }^{3}$ Within a few years it was being applied to a variety of problems, including inflammations of the eye, acute rheumatism, uterine pain, and delirium tremens. ${ }^{4}$ This early literature on subcutaneous injection of morphia was unreservedly euphoric about its uses. Injected morphia was lauded as being more effective than ingested opium, and free from opium's more unpleasant side effects, such as constipation and stupor. In 1869, Dr. Edward Wilson began an article on subcutaneous injection of morphia by stating that "few really important discoveries have glided so silently into every-day use as the subcutaneous injection of remedial agents. Slowly and surely this new method has won its way and established itself in the profession until there are probably few medical men now to be found who cannot bear testimony, from their own experience, to the marvellous power of narcotics introduced beneath the skin."5 Wilson reviewed the possible uses of injected morphia, and concluded by calling it "the greatest boon given to medicine since the discovery of chloroform." 6 In the same year, Dr. Arthur Evershed chided his "professional brethren" whose misplaced caution about injected morphia kept them from using this "means of relief so satisfactory to their patients and to themselves". 7 The only note of caution in the papers of the 1850 s and 1860 s concerned the dangers of poisoning through an overdose: the line between a therapeutic and a toxic dose of morphia could be very thin indeed.

There was a substantial medical literature on opium in Latin and, increasingly, in English. In the seventeenth century, it had been so highly praised by Dr. Thomas Sydenham that it had earned him the sobriquet "Opiophilos". His widely-publicized formula for tincture of opium continued to be known as "Sydenham's Laudanum" well into the nineteenth century. ${ }^{8}$ Opium had been the subject of books and papers by both clinicians and toxicologists in the eighteenth and nineteenth centuries. 9

${ }^{3}$ Alexander Wood, 'Treatment of neuralgic pains by narcotic injections', Br. med. J., 28 August 1858, 721-723. Also idem, 'A new method of treating neuralgia by the direct application of opiates to the painful points', Edin. med. surg. J., 1855, 82: 265-281; Charles Hunter, 'On narcotic injections in neuralgia', Med. Times Gaz. , 1858, 17: 408-409; idem, 'On narcotic injections in neuralgia', ibid., 457-458; idem, 'A series of narcotic injections into the cellular tissue in neuralgia and other diseases', Br. med. J. , 8 January 1859, 19-20; idem, 'Practical remarks on the hypodermic treatment of disease', Lancet, 1863, ii: 444-445, 675-676; idem, On the speedy relief of pain and other nervous affections by means of hypodermic method, London, 1865; idem, 'Hypodermic administration of certain medicines', Med. Times Gaz., 1865, 1: 584-587.

$4 \mathrm{~J}$. Zachariah Laurence, 'The antiphlogistic powers of morphia illustrated by its use in the treatment of acute inflammations of the sclerotic and iris', Med. Times Gaz., 31 December. 1859, 651-652; John K. Spender, 'The hypodermic action of morphia', Br. med. J. , 9 June 1860, 436-437; J. Henry Bennet, 'On the hypodermic treatment of uterine pain', Lancet, 1864, i: 296-297; W. Ogle, 'Injection of acetate of morphia into the cellular tissue of the arm, in delerium tremens', Med. Times Gaz. , 21 July 1869, 54-55. For a detailed study of the development of hypodermic medication, see Norman Howard-Jones, 'A critical study of the origins and early development of hypodermic medication', J. Hist. Med, 1947, 2: 201-247.

5 Edward T. Wilson, 'Notes on the subcutaneous injection of morphia', St. Geo. Hosp. Rep., 1869, 4: 19.

6 Ibid., p. 30.

7 Arthur Evershed, 'On the hypodermic injection of morphia', Med. Times Gaz., 1 May 1869, 463.

8 Joseph F. Payne, Thomas Sydenham, London, T. Fisher Unwin, 1900, p. 182.

9 Melvin P. Earles, 'Studies in the development of experimental pharmacology in the 18th and early 19th centuries', unpublished Ph.D. thesis, University of London, 1961. 


\section{Terry M. Parssinen and Karen Kerner}

Throughout these writings there is a recognition of such phenomena as patient dependence, physiological tolerance, and withdrawal pains. John Jones, in 1701, accurately described withdrawal symptoms:

The Effects of going off (or declination) of the Operation of Opium, taken internally in a moderate Dose:

1. A general return of all the Diseases and Disasters Opium palliated during its Operation; . . .

2. Sweat, tho' not constantly.

3. Frequent making of water, sometimes.

4. A Looseness (sometimes) even when there was none before the giving of Opium.

5. Diseases, seeming worse than before the taking of it.

6. A melancholy and sad Depression of Spirits.

7. A narrow Pulse.

8. Itching of the Skin. 10

Samuel Crumpe, in 1793, noted that regular opium users, when deprived of the drug "for a single day, became languid, dejected, and uneasy at the customary hours of taking it, and could only be roused from this state by the usual quantity of Opium, or by a large draught of wine"."11 Sir Astley Cooper, in an 1824 lecture on poisons, described the deleterious effects of long-term opium use, including patient dependence: "This irritable state of nerves, produced by opium, is relieved by a fresh dose: it becomes absolutely necessary to the patient, and the nervousness produced by the opium of yesterday is relieved by the opium of today." 12 Yet there was little tendency by medical men to take these warnings very seriously, and certainly there was no attempt to define addiction as a disease.

The first paper addressed to the addictive properties of morphia was published by Dr. Thomas Clifford Allbutt in 1870:

Does morphia tend to encourage the very pains it pretends to relieve; or if not, does it at any rate induce in those who use it constantly, an artificial state which makes its further use a necessity? Are the subjects of morphia injection, that is, liable to become depressed, relaxed, irritable and dependent on a new habit of constant intoxication? If this be so, we are incurring a grave risk in bidding people to inject whenever they need it, and in telling them that morphia can have no ill effects upon them so long as it brings with it tranquility and wellbeing. 13

In retrospect, this appears extremely tentative, although in contrast to the enthusiasm of his colleagues in the previous decades, Allbutt must have seemed a Cassandra. The paper touched off a small debate in the Practitioner, in which Drs. Oliver and Anstie, while not denying that morphia injections could create patient dependence, argued that this occurred relatively infrequently, and could be easily avoided. 14

THE DISEASE MODEL OF DRUG ADDICTION: LEVINSTEIN AND KERR

Unquestionably the most important contribution to the addiction literature of the late nineteenth century was Edward Levinstein's Die Morphiumsucht, translated into

10 John Jones, The mysteries of opium reveal'd, London, 1701, pp. 27-28.

11 Samuel Crumpe, An inquiry into the nature and properties of opium, London, 1793, p. 178.

12 Sir Astley Cooper, 'On vegetable and mineral poisons', Lancet, 1824, ii: 171.

13 Thomas Clifford Allbutt, 'On the abuse of hypodermic injections of morphia', Practitioner, 1870, 5 , 329-330.

14 George Oliver, 'On hypodermic injections of morphia', ibid., 1871, 6: 75-80; and F. E. Anstie, 'On the effects of the prolonged use of morphia by subcutaneous injection'; ibid., 148-157. See also J. Pennock Sleightholme, 'Hypodermic morphia in a general hospital', ibid., 1871, 7: 23-28. 
Development of the disease model of drug addiction in Britain, 1870-1926

English in 1878 as The morbid craving for morphia. The most significant feature of this book is the form in which it was cast, with sections on symptomatology, aetiology, prognosis, and prophylaxis. Levinstein was not simply warning his colleagues about unpleasant side effects of a new drug therapy; he was describing a new disease: "the uncontrollable desire of a person to use morphia as a stimulant and a tonic, and the diseased state of the system caused by the injudicious use of the said remedy". 15

Of utmost importance in Levinstein's case is his argument that the morbid craving for morphia is not a form of mental alienation. In contrast to fellow-German psychiatrists Lähr and Fiedler, Levinstein stressed that "the desire for morphia injections . . . results from [a person's] natural constitution and not from a certain predisposition to its use." 16 Levinstein was insistent upon the somatic origins of drug addiction because only by doing so could he convince his medical colleagues to take it seriously as a disease. A mechanical model of disease, which virtually ruled out nonsomatic causation, was at the height of its influence in the third quarter of the nineteenth century. While later developments would make psychic diseases medically respectable, a different wind prevailed in the 1870 s, and Levinstein trimmed his sails accordingly.

Levinstein dealt with morbid craving for morphia like any other disease. The treatment that he prescribed is what is known, in American parlance, as "cold turkey". The patient is to be locked in a set of rooms "for a period of eight to fourteen days, all opportunities for attempting suicide having been removed", attended by nurses and overseen by a physician. ${ }^{17}$ In order to see him over the more difficult periods of withdrawal pain, the patient is allowed recourse to warm baths, bicarbonate of soda, chloral hydrate, and, interestingly enough, unlimited amounts of champagne and brandy. Only in the case of a patient's complete collapse, with the threatened loss of life, should the physician resort to an injection of half a grain of morphia. After four weeks, at the most, patients can be returned to society. Levinstein was unconcerned about relapse: once a patient was restored to physical health, Levinstein considered him cured. He was similarly sanguine in his description of "prophylaxis": "We shall not be wrong in saying that morbid craving for morphia, after the lapse of several years, will be of rare occurrence in Germany, as soon as the governmental decrees, already issued by some of the states, are obeyed; the doctors in future not allowing the morphia injections to be practised by anyone but themselves." 18 From the perspective of the present, Levinstein's formulation seems particularly antiquated, both in its rigidity, and in its naivety. But we should not underestimate its appeal in the 1870 s. It was a forceful statement of a problem about which medical men were anxious, in a form which they recognized as appropriate.

The most important British spokesman on the question of addiction in the late nineteenth century was Dr. Norman Kerr, the founder and first president of the Society

15 Edward Levinstein, Morbid craving for morphia, London, Smith, Elder, 1878, p. 3. Another German whose papers were occasionally published in English was Dr. H. Obersteiner, 'Chronic morphinism', Brain, 1879-1880, 2: 449-465, and 'Further observations on chronic morphinism', ibid., 1882-1883, 5: 324-331.

16 Levinstein, op. cit., note 15 above, p. 7.

17 Ibid., p. 113.

18 Ibid., p. 126. 


\section{Terry M. Parssinen and Karen Kerner}

for the Study and Cure of Inebriety, mercifully abbreviated as SSI. The SSI was founded, in 1884, as an association of eminent medical men, "to investigate the various causes of inebriety, and to educate the professional and public mind to a recognition of the physical aspect of intemperance." 19

The central message of Kerr and his SSI associates, which recurs like an incantation throughout their publications, is that "inebriety is a disease". Kerr claimed that inebriety "is for the most part the issue of certain physical conditions . . . the natural product of a depraved, debilitated, or defective nervous organization, ... as unmistakably a disease as is gout, or epilepsy, or insanity." 20 In his book, Inebriety or narcomania, Kerr accepted the "narrow" definition of disease as the result of a structural alteration which can be pathologically verified, and then attempted to demonstrate how alcoholic inebriety clearly conforms to it.21

What was at stake for Kerr and his associates was far more than a mere question of medical classification. Until the present time, they claimed, society has condemned the inebriate as a sinner, or punished him as a criminal, but it has not seen him for what he really is - a sick man. If inebriety, like gout or epilepsy, is the result of a physical defect over which the sick person has no control - that is, if inebriety is not a wilful act - then the inebriate should not be gaoled, but hospitalized. This is the essence of the case made by Kerr and his associates in the late nineteenth century, in their attempt to secure legislation which would create publicly-funded retreats for the treatment of inebriates. They were not very successful. The Habitual Drunkards' Act of 1879 and the Inebriates' Act of 1898 did license a few retreats, but they were private, and received only minimal public support. Above all, the acts did not allow for the confinement of non-criminal inebriates against their will, as the Lunacy Acts had done for the mentally ill. Late Victorian legislators, moved equally by a niggardliness with public funds and a greater regard for the liberty of the citizen than the necessity of therapeutic confinement, ultimately frustrated Kerr and his colleagues.22

Nevertheless, in their efforts to build a case for compulsory confinement, the SSI produced a very considerable number of scientific publications which were crucial in shaping the idea of drug addiction in Britain. Kerr and his colleagues were most concerned about alcoholism, which they rightly regarded as the most significant form of inebriety in Britain. But they also wrote about other "narcotizing agents", including opium, chloral hydrate, chlorodyne, and cocaine. Kerr claimed that "the opium habit" is a "true inebriety", although it is a "functional neurosis", in which "organic lesions are comparatively rare." 23 Altogether, in contrast to alcoholism, the opium habit is much less dangerous, both as a social, and as a physical disease: "The opium inebriate does not destroy his furniture, beat his wife, bash his child's head against the wall, or pursue his narcotic career dealing with his hand death and desolation all around. Nor

19 Proceedings of the SSI, July 1884, no. 1, p. 1. The SSI grew out of an older organization, the Society for Promoting Legislation for the Control and Cure of Habitual Drunkards, which had been founded in 1876.

20 Ibid., p. 3.

21 Norman Kerr, Inebriety or narcomania. Its etiology, pathology, treatment and jurisprudence, 3rd ed., London, H. K. Lewis, 1894, pp. 10-11.

22 Roy M. Macleod, 'The edge of hope: social policy and chronic alcoholism 1870-1900', J. Hist. Med., 1967, 22: 215-245.

23 Kerr, op. cit., note 21 above, pp. 100-101. 
does he, as the tippler of alcohol, so degenerate his tissues, injure the structure of his vital organs, or originate organic disease, by the direct poisoning action of the stupefying agent which consigns him to an early grave." 24 Yet, Kerr claimed, "opium transcends alcohol in the generation of a more irreclaimable and incurable diseased condition. Cured alcohol inebriates are not uncommon [but] . . . cured opium inebriates are comparatively few in number." 25 Although he regarded opium-smoking and opium-eating as harmful, Kerr believed that "the hypodermic injection of morphia is, however, the most swift and the most potent of all the methods of administration."'26

Finally, Kerr addressed the objection that some persons can use moderate amounts of intoxicants, even opium, without damaging themselves. This argument, which was made frequently in Britain in the 1890 s, naturally tended to undercut the idea that opium-taking, in whatever form, was a disease. Kerr's reply to this is a classic example of the way in which moral judgments were intertwined with scientific facts in his writings: "Opium is a poison which excites, intoxicates, and enervates the whole man; by repeated indulgence inducing bodily and mental prostration and moral perversion." 27 Kerr personally, and the SSI in general, publicized in British medical circles the idea that inebriety, including drug addiction, was a disease, whose treatment was properly the responsibility of the physician. In addition, Kerr modified Levinstein's conception of the disease of addiction by stressing that it had a psychological aetiology, and by emphasizing the difficulty of reversing a patient's opium habit once it was fully established. Both of these themes became prominent in the twentieth-century literature on addiction.

\section{THE OPIUM APOLOGISTS}

While Kerr and his colleagues laboured to establish the disease model of addiction in the 1880 s and 1890 s quite a different evaluation of the effects of opium was being put forward by a group of medical men and politicians writing in defence of the opium trade between British India and China. Their publications were provoked by the antiopium publicity generated by the Society for the Suppression of the Opium Trade, a Quaker-based organization, founded in 1874. The SSOT was dedicated to forcing the Indian government out of the lucrative business of supplying Chinese smokers with opium grown on a government monopoly. The society argued that Britain was morally compromised by selling opium - "a poison" - to the Chinese, and demanded that the trade cease at once. 28

The opium apologists met this argument on several different levels. There was, to begin with, the economic issue. Sir Rutherford Alcock and Sir George Campbell

24 Ibid., pp. 102-103.

25 Ibid., pp. 105-106.

26 Ibid., p. 109.

27 Ibid., p. 117.

28 Bruce D. Johnson, 'Righteousness before revenue: the forgotten moral crusade against the IndoChinese opium trade', J. Drug Issues, 1975, 5: 304-326. On the opium trade itself, see David Owen, British opium policy in China and India, New York, Academy Press, 1928; Peter W. Fay, The opium war, 1840-1842, Chapel Hill, University of North Carolina Press, 1975; and Brian Inglis, The opium wars, London, Hodder \& Stoughton, 1976. 


\section{Terry M. Parssinen and Karen Kerner}

argued that, despite the hypocritical denunciations of Indian opium, the Chinese government allowed opium to be grown within its own borders. Given the constant demand for opium by Chinese smokers, the only effect of a ban on Indian opium imports would be an increase of tax revenue for the Chinese government, while the government of India suffered accordingly. 29

A somewhat different, although complementary line was argued by several eminent medical men, who had served in the opium-eating regions of India, and the opiumsmoking regions of China. Sir George Birdwood wrote two letters on the subject which were published in The Times in 1881 and 1882: "As regards opium-smoking", he claimed, "I can from experience testify that it is, of itself, absolutely harmless." 30 And, of opium-eating, he declared that "sound, hale people, in comfortable circumstances who lead healthy lives, seldom or never suffer from the habitual use of opium, even in quantities that seem to be excessive. There are few finer people in the world than those of Goojerat, Kattywar, Cutch, and Central India, and they are all addicted to the habitual use of opium."31 Surgeon-General Sir William Moore stated flatly that "opium is not the destructive agent which anti-opiumists have declared it to be." 32 To those who claimed that the prolonged use of opium is deleterious to health, Moore replied: "I assert that there is no organic disease traceable to the use of opium. Functional disorders, more or less, may be induced by excessive use of opium. But the same may be said of other causes of deranged health - gluttony, tea, tobacco, bad air, mental anxiety, etc." 33 In fact, Moore asserted, those Indians who use opium regularly and moderately are in better health than those who do not.

Finally, both Moore and F. J. Mouat, formerly a government medical inspector in India, declared that opium-eating was a much less serious social problem than alcoholdrinking. ${ }^{34}$ "Has an opium-eater ever been found to have knocked out his wife's brains?" Mouat asked, "Is that civilised proceeding altogether unknown to the alcoholic drunkard at home?"35 If opium were banned in India and China, they argued, the result would be to drive opium-users to more harmful stimulants, like alcohol or ganja.

The capstone to the opium apologists' argument came in the unlikely form of a parliamentary blue book. In 1893, in response to the successful agitation by antiopiumists, Gladstone and the Liberal government of the day created a Royal Commission to investigate opium-growing and opium-eating in India, and to make recommendations on policy changes. In 1895, after two years of interviews with experts in both London and India, the commission published its final report. Much to the dismay of the anti-opiumists, the report was a complete endorsement of the views

29 Rutherford Alcock, 'Opium and common sense', Nineteenth century, 1881, 10: 854-868; idem, 'The opium trade', originally published in J. Society and Arts, 20 January 1882, reprinted in Hartmann Henry Sultzberger (editor), All about opium, London, 1884, pp. 27-66; 'Sir George Cambell's letter to the "Times”,' ibid., pp. 191-193.

30 'Sir George Birdwood's first letter to "The Times", ibid., p. 22.

31 Ibid., p. 24.

32 William J. Moore, 'Opium: its use and abuse', Med. Reporter, 1892, 1 : 224.

33 Ibid., p. 225.

34 W. J. Moore, 'The opium question', Ind. med. Gaz. , 1880, 225-230, 257-264; and F. J. Mouat, 'The ethics of opium and alcohol', Lancet, 1892, ii: 1090-1092, 1152-1154.

35 Ibid., p. 1092. 
of the opium apologists. The commissioners found little evidence that opium-eating led to the physical or moral decay of users. To the contrary, they found that opium was used intelligently as a medicine, in moderation as a stimulant, and that to deprive the natives of the drug would cause great suffering. ${ }^{36}$

The report was widely publicized in the medical press, and caused consternation among those who argued that opiate addiction was a disease. How could a substance which had been found to be harmless, and even beneficial, in India, be so pernicious in England? The Opium Commission Report put the disease theorists on the defensive. Virtually every discussion of the problem in the fifteen years after 1895 made mention of the report. The only paper published by the SSI in an attempt to reassert the disease theory of addiction in the face of the report's evidence was rambling and unconvincing. ${ }^{37}$ Yet in spite of its undoubted influence, the Opium Commission Report did not refute the disease theory of addiction. The report delayed its triumph by making its proponents somewhat more cautious, and its audience somewhat more sceptical. But in the end, the report was only a rearguard action.

\section{THE DISEASE MODEL OF ADDICTION FROM THE 1890S THROUGH 1916}

From the 1890s until 1916, a number of books and articles were published which addressed the issue of drug addiction. In addition, the leading medical textbooks began to include a chapter on the topic. The fundamental disputes of the nineteenth century had either been resolved or brushed aside, and a wide consensus emerged on most of the important aspects of a theory of drug addiction.

(1) Drug addiction is a disease like alcoholism; but narcotic drugs, while less damaging in their social effects, are more ruinous for the individual user. Although all were in agreement with this central tenet, there was still considerable room for manoeuvre. J. B. Mattison adhered to a "physicalist" definition of drug addiction: "Tersely stated, it may be said that this disease involves the cerebro-spinal and sympathetic systems, well attested clinical fact proving that they bear the brunt of opium excess, which induces changes that give rise to great nervous derangement, when the opiate is withdrawn, and which, in gradual withdrawal, is seldom entirely avoided." 38 Harrington Sainsbury, however, claimed that addiction was "a form of Moral Insanity", 39 and Sir William Collins called it "a disease of the will". 40 Allbutt and Dixon termed addiction "a vice", and included the censorious warning that "nowadays whoso betakes himself to the morphia syringe does so of his own naughtiness". ${ }^{41}$ In fact, these definitions did not reflect fundamental disagreements among the authors, but rather differing emphases on parts of the same problem. If one

36 Royal Commission on Opium, Final report, Parliamentary Papers, 1895, vol. 62, p. $31 \mathrm{ff}$.

37 William Huntley, 'Opium addiction: is it a disease?' Proc. SSI, November 1896, no. 50, pp. 1-12.

38 J. B. Mattison, 'The treatment of the morphine disease', ibid., August 1892, no. 33, p. 1. Mattison and T.

D. Crothers, although Americans, were highly regarded in Britain. Their work was well known, and Mattison was an honorary member of the SSI. Another American physician, H. H. Kane, whose many books on drug addiction were published in the $1880 \mathrm{~s}$, was not influential in Britain.

39 Harrington Sainsbury, Drugs and the drug habit, London, Methuen, 1909, p. 223.

40 Sir William Collins, 'The ethics and law of drug and alcohol addiction', Br. J. Inebr., 1916, $13: 141$.

41 T. Clifford Allbutt and W. E. Dixon, 'Opium posioning, and other intoxications', in Thomas Clifford Allbutt and Humphry Davy Rolleston (editors), A system of medicine by many writers, London, MacMillan, 1906, vol. 2, pt. 1, p. 949. 


\section{Terry M. Parssinen and Karen Kerner}

considered the disease of addiction simply in terms of the morbid effects of opiates on the central nervous system, then the physicalist definition was quite adequate. But Sainsbury and Collins, by borrowing contemporary psychiatric terminology, were really trying to answer the question of why a person voluntarily habituates himself to morphia. Allbutt and Dixon, in addressing the same question, slipped into an older vocabulary, derived from a traditional morality, as Kerr had occasionally done in the previous decade. Essentially the problem was how to describe a disease in which some persons, at least, wilfully adopted a course of self-destruction, with full knowledge of its probable consequences.

T. D. Crothers made the most ambitious attempt to resolve this problem by distinguishing between "morphinism" and "morphinomania". The former "describes a condition following the prolonged use of morphin . . ." while the latter designates "the condition of persons in whom the impulse to use morphin is of the nature of a mania, possessing the mind and dominating every thought, leaving but one supreme desire - to procure morphin and experience the pleasure it gives". ${ }^{42}$ The morphinist, although he had contracted the physical habit, retained his moral sensibilities and sanity, whereas the morphinomaniac had lost both. Yet even Crothers admitted that this theoretical distinction, which separates out the two elements of addiction, was of limited utility in identifying patients: "The morphinist not infrequently becomes a morphinomaniac .... These two classes are not always marked. They frequently merge into each other, making it difficult to distinguish between them." 43 Although Crothers' solution was inadequate, he clearly recognized and addressed a problem which continues to plague drug researchers today: how does one satisfactorily describe a disease which has both physiological and psychological elements?44

(2) Some persons have a psychological predisposition to the use of stimulants generally, and these people will often switch from one drug to another, or use them in combination. Many persons change to alcohol in an attempt to break a morphia habit, or vice versa, and remain addicted to both. Lawton, Jennings, and Crothers all agreed that the type most disposed to become drug addicts were "neurotics"; that is, those persons who had inherited a defective nervous system. ${ }^{45}$ Allbutt and Dixon defined neurotics as persons "who scent intoxicants from afar with a retriever-like instinct, and, curious in their sensations, play in and out with all kinds of them." 46 Jennings stressed the futility of distinguishing among different kinds of addiction because narcotics were used so interchangeably by addicts: "It may be objected that cocainism is not morphinism, but this would be an error, for it is exceptional for a cocaine addict not to take morphia as well. Heroin-taking is also on the increase, and this synthetic

42 T. D. Crothers, Morphinism and narcomanias from other drugs, Philadelphia and London, W. B. Saunders, 1902, p. 42.

43 Ibid., p. 43. See also pp. 44-45, 56.

44 See also Francis Hare, 'The withdrawal of narcotics from habitués', Br. J. Inebr., 1910, 8: 86; Oscar Jennings, The morphia habit and its voluntary renunciation, London, Baillière, Tindall, \& Cox, 1909, pp. 2, 29, 44-45; Walter Lawton, 'Stimulants and narcotics and their users and abusers', Pharm. J. , 29 February 1908, p. 268; Huntly, op. cit., note 37 above, pp. 4-5; and William Osler, The principles and practice of medicine, London and Edinburgh, Y. J. Pentland, 1894, p. 1005.

45 Lawton, op. cit., note 44 above, p. 269; Jennings, 'On the physiological cure of the morphia habit', Lancet, 1901, ii: 361; and Crothers, op. cit., note 42 above, pp. 57, 134.

46 Allbutt and Dixon, op. cit., note 41 above, p. 951. 


\section{Development of the disease model of drug addiction in Britain, 1870-1926}

alkaloid being a derivative of morphia, heroin addiction is, to all intents and purposes, identical with morphinism." 47

(3) Most drug habits are therapeutically-induced. A patient is given morphia and perhaps instructed in the use of a syringe by his doctor. After using morphia regularly for a period of weeks or months, he finds that he is unable to do without it. Allbutt and Dixon noted that addiction is particularly easy for those who begin to use morphia for "pain which is wearisome rather than acute". ${ }^{48}$ Sainsbury claimed that most persons "fly to drugs . . . to escape a distress of mind or body". ${ }^{49}$ Crothers confessed that given its therapeutic importance, "actually no known dividing-line exists between the use and abuse of morphin".50

(4) Morphia addiction is a disease of "modern civilization", which particularly afflicts those who feel its pressures most acutely. As early as 1876, Benjamin Ward Richardson had devoted a chapter to drug addiction in his Diseases of modern life. T. D. Crothers echoed the same theme twenty-five years later, when he said that morphinism was due "in large measure to modern civilisation, associated with the rapid exhaustion following changes of life and living". He claimed that morphia was the popular antidote to those newly-emergent nervous diseases, "neurasthenia and cerebrasthenia".51 Morphinism is particularly prevalent among "active brainworkers, professional and businessmen, teachers and persons having large cares and responsibilities". 52 Lawton noted that in addition to neurotics, persons of "artistic temperament", including "geniuses", often succumb to addiction. ${ }^{53}$ Osler claimed that "the habit is particularly prevalent among women and physicians". Mattison agreed that "medical men . . . compose the better class of habitués",54 and Jennings was so impressed by the percentage of medical men among his addict patients that he ventured the estimate that one out of every four medical men was addicted to narcotic drugs. 55

(5) While it is true that a few addicts can carry on a completely normal life so long as they are not deprived of the drug, most will begin to show symptoms of physical, psychological, and moral decline after prolonged use. Allbutt and Dixon gave a typical description of the process of degeneration:

But if the habit be continued and the doses increased, as will be assuredly the case and that quickly, symptoms of bodily disease will appear; say in six or eight months at farthest. The flesh begins to fall; the face loses colour and takes on a sallow, lustreless hue and an aged expression; the teeth are loosened, and gradually even a young person becomes wizened, emaciated, and haggard. To this rule there are some exceptions; a few patients keep their flesh, or even grow fat and puffy: such persons are good feeders, take wine freely, and probably escape the catarrh of the stomach which attacks the greater number of their fellows. Constipation is always present, often in most obstinate degrees; the mouth is parched, and other secretions as a rule are arrested; though some morphinists sweat profusely. Still, for many years life goes

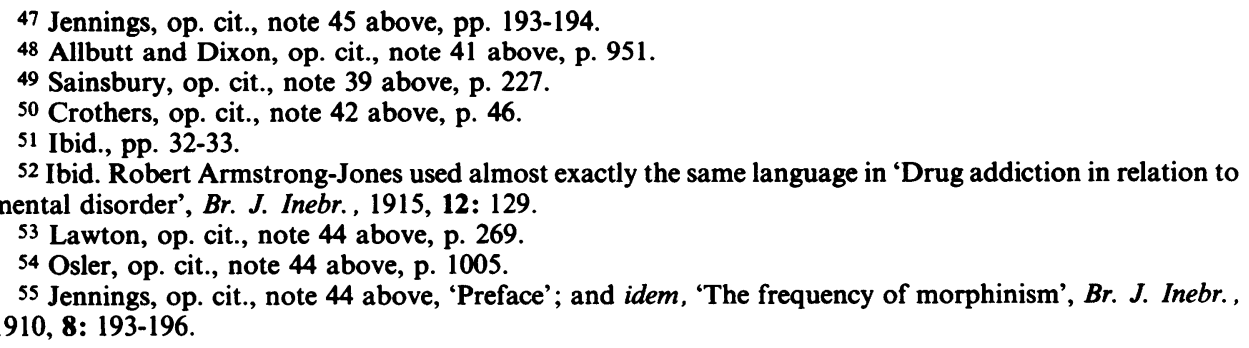




\section{Terry M. Parssinen and Karen Kerner}

on, and the constitution does not break up: morphinists do not, however, live to full age; and, if the habit be contracted in old age, the patient fades away in no long time. In younger subjects the social affections grow cold; waywardness and caprice deepen into selfishness and physical and moral degradation; the fitful charms of character or the powers of mind, if any such there were, are blotted and spent; memory fails; amenorrhoea and sterility overtake the woman, and impotence the man; irregular febrile attacks appear; albumin may be found in the urine; even sleep is heavy, or is exhausting and disturbed by hallucinations; abscesses arise at the punctures of the unclean needle, and heal badly; the mouth is dry; the teeth decay; gastric catarrh increases, with symptoms of nausea, retching and flatulence, and of an epigastric or substernal pain which is rather too characteristic of morphinism to be put down merely to catarrh; the thread of life grows frailer; all capacity for fitful work disappears; the intercurrent miseries of the habit are intensified, the moments of excitement briefer and less effectual, until the patient curses the day he was born: in later middle life at farthest he dies, usually cut off quickly by some chance malady. ${ }^{6}$

(6) Gradual withdrawal over a period of several days or two or three weeks is preferable to either sudden withdrawal or drug substitution. Allbutt and Dixon, writing in 1906, noted that "the chief and most grievous symptom is the dangerous collapse which may follow withdrawal, and if the withdrawal be sudden it may reach an alarming and even fatal degree." But they added that "as the sudden withdrawal of morphine is no longer practised this collapse may pass out of observation." 57 The writers who touched on the subject agreed on the superiority of gradual withdrawal, although a few added modifications. Jennings stressed the importance of modifying the speed of the withdrawal to the ability of the patient to sustain it;58 Hare advocated sudden withdrawal for those recent addicts who had built up little tolerance for the drug; 59 and Crothers suggested that "a certain number of persons whose addiction has continued for many years, and who have passed middle life and are very much debilitated physically and mentally" might be maintained on morphia under a physician's care. 60

(7) The prognosis for the cured patient depends upon many factors. Osler voiced the widespread opinion that "after an apparent cure the [addict] patients are only too apt to lapse into the habit".61 Perhaps understandably, his pessimism was not shared by those physicians who specialized in curing addicts. Allbutt and Dixon cited the high failure rate for others, but claimed that "on the whole, our own cases have shewn no inevitable tendency to relapse". 62 Jennings, who admitted that he took only those patients who showed a strong desire to be cured, claimed an astounding success rate of ninety per cent. 63 Lawton wrote that "morphinism is very curable", although he regarded those addicted to cocaine as beyond hope. 64 The most careful consideration of the question of relapse was written by T. D. Crothers: "The prognosis in

\footnotetext{
56 Allbutt and Dixon, op. cit., note 41 above, pp. 954-955. See also Osler, op. cit., note 44 above, p. 1006 ; Lawton, op. cit., note 44 above, p. 545; Jennings, op. cit., note 44 above, pp. 14-18; Jennings, op. cit., note 55 above, p. 194; A. H. Prichard, 'An aspect of the morphia habit in an early stage', Clin. J. , 5 August 1903, p. 256; Sainsbury, op. cit., note 39 above, pp. 219-223; Huntley, op. cit., note 37 above, p. 9 ; and Crothers, op. cit., note 42 above, pp. 45-53, 106-115.

57 Allbutt and Dixon, op. cit., note 41 above, p. 958 . This had not always been the case; see S. J. Sharkey, 'The treatment of morphia habitués by suddenly discontinuing the drug', Lancet, 1883, ii: 1120-1121.

58 Jennings, op. cit., note 45 above, p. 361 .

59 Hare, op. cit., note 44 above, p. 87.

60 Crothers, op. cit., note 42 above, p. 141.

61 Osler, op. cit., note 44 above, p. 1007.

62 Allbutt and Dixon, op. cit., note 41 above, p. 962

63 Jennings, op. cit., note 44 above, p. 9.

64 Lawton, op. cit., note 44 above, p. 570.
} 
morphinism will vary very widely according to the condition of the patient, the length of time of the addiction, and the influence of heredity." 65 The possibility of a cure, he believed, is especially doubtful in cases in which the patient has a long-standing addiction, a chronic disease, a neurotic temperament, or a second addictive drug habit. All such patients invariably relapse. 66

Even on the question of treatment, about which many heated words were exchanged, the writers were in agreement on the major issues: patients must be isolated in an asylum or other institution; and substitution of such drugs as cocaine, cannabis indica, or even heroin - which had been variously recommended in the last three decades of the nineteenth century - was a terrible mistake. They disagreed only on the minor and technical questions of how best to manage a patients undergoing treatment, and how to alleviate withdrawal pains. Mattison recommended regular doses of sodium of bromide to subdue the "aches, pains, yawning, sneezing, shivering, nausea, vomiting, diarrhoea, restlessness, delirium, convulsions, exhaustion, [and] collapse" which are "incident to sudden opiate quitting" ${ }^{67}$ Crothers noted that many patients are dependent upon the needle, and that injections must be continued during withdrawal, even if they contain only minute traces of the drug. 68 Jennings proselytized for his "therapeutic triad" of heart tonics, bicarbonate of soda to neutralize hyperacidity, and Turkish or hot-air baths as a sedative. ${ }^{69}$ Allbutt and Dixon disagreed with Jennings' advocacy of heart tonics, and preferred hot water enemas to bicarbonate of soda for diarrhoea. But, they claimed "whatever the value of auxiliary drugs, the importance of nourishment is much greater .... When the nausea or vomiting are troublesome, coldmeat jellies, iced coffee with or without cream, iced champagne, and the like, must be tried by the mouth, and supplemented by nutritive enemas. As the stomach becomes more capable of work, turtle and other strong soups, and like generous and restorative foods, must be pressed on the patient; and gentle massage used to promote absorption and blood formation."70 These heated exchanges over the relative values of Turkish baths, champagne, and turtle soup may have absorbed their authors, but in fact they represent little real divergence of opinion. On the important issue, British physicians agreed about how to cure drug addiction.

\section{PORTRAYAL OF DRUG ADDICTION IN POPULAR LITERATURE}

By 1910 , then, the disease model of drug addiction was mature. Although it had originally been developed in the professional medical literature, it eventually filtered into popular fiction and journalism. ${ }^{71}$ Particularly in the decade after 1908 , there was an outburst of popular writings on the subject. One can see, through the raging emotions, the ruined virgins, and the conspiratorial Chinese of these tales, the clear outline of the disease model of drug addiction that had been developed by medical

65 Crothers, op. cit., note 42 above, p. 139.

66 Ibid., pp. 139-141.

67 Mattison, op. cit., note 38 above, p. 1.

68 Crothers, op. cit., note 42 above, p. 173.

69 Jennings, op. cit., note 45 above, passim; and op. cit., note 44 above, passim, esp. pp. 6-7.

70 Allbutt and Dixon, op. cit., note 41 above, p. 256; and Hare, op. cit., note 44 above, pp. 89-90.

71 The popularization had begun as early as the $1880 \mathrm{~s}$, most notably with Seymour Sharkey's 'Morphinomania', Nineteenth Century, 1887, 22: 335-342. 


\section{Terry M. Parssinen and Karen Kerner}

writers in the previous decades. Consider, for example, this fairly typical piece of pulp fiction: "The grey land of drugs. Arranged from the confessions of a sojourner. By Kate Jordan", published in Pearson's Magazine in 1916.

The heroine is a young widow, who becomes a drug addict to assuage the physical and psychic pain she feels immediately after the death of her husband. She begins by taking orally the morphia that has been prescribed for her by her physician. Her habit grows from half a grain to six grains per day by the end of the year. Her behaviour changes from eccentricity to mania. When an old friend guesses that she is a morphiataker, the heroine denies it, and breaks off their friendship. She moves to London, but continues to deteriorate, both physically and morally, becoming a recluse and a shoplifter. Eventually she meets a fellow-addict from whom she learns how to inject morphia hypodermically: "It is true a twinge of my native fastidiousness made me shudder when I first saw the secret parts of her body lacerated and green from a thousand needle pricks, with scattered inflammations and small ulcers; but this oozed away, as did all normal sensations, to become a part of the haze in the grey land where I was a psychic cripple, drifting to complete demoralisation." 72 In the company of her fellow addict, our heroine squanders all of her capital, and reaches the depths of human existence:

The last stages of my debilitation had set in. In my old clothes I only went out at night. My drugged days were spent reading trashy, exciting romances picked up by the armful at second-hand book-shops, and talking gibberish to animals ... . I had been growing steadily unclean. Soon I dispensed with my maid, and the home grew a well of disorder. I ceased changing my clothing or my undergarments. I ceased taking baths; even the thought of freshening water on my flesh would put an edge on my teeth. From tolerating dirt I came to find warmth, even comfort, in bodily staleness .... Though my dose of poison was now very heavy, its effects were failing. No longer that first feeling of bien-être! No more hazy beatitudes! . . . As this could not be endured without a palliative of some sort I began to drink whiskey. My calloused senses to be affected required large quantities of it, and I took it raw. All this before I was thirty. ${ }^{73}$

Suffice it to say that our heroine is finally rescued by her rejected but faithful friend, who brings her to her senses. She undergoes a gradual detoxification programme, and is restored - almost - to her former self: "Yet it would be futile to suppose that anyone could have lived so long debased and come so close to death, and bear no marks. My health will never fully return. I must always hide my needle-corroded arms. But this is a small price, after all, for sanity and fearless eyes to meet the clean sweet sun!'74

Thus the disease theory of drug addiction, in virtually every specific, was translated into popular literature, and the image of the drug user was transformed from the unfortunate but fairly normal habitué of the nineteenth century, into the crazed dope fiend of the twentieth. 75

\section{EFFECT OF THE DISEASE MODEL OF DRUG ADDICTION ON NARCOTICS POLICY}

In the 1920s, the disease model of addiction was challenged from a new direction. In

72 Kate Jordan, 'The grey land of drugs. Arranged from the confession of a sojourner', Pearson's Magazine, 1916, p. 306.

73 Ibid., p. 307.

74 Ibid., p. 308.

75 Other contemporary fiction embodying the disease theory of drug addiction includes Maud Diver, The great amulet (1908): Sax Rohmer, Dope: a story of Chinatown and the drug traffic (1919), Aleister Crowley, The diary of a drug fiend (1922); and Mary Lake, The drug slave (1913). 
the United States, legislation intended to curb or prohibit the use of narcotic drugs had been enacted at the state and local levels from the 1870s, and at the federal level somewhat later. The Harrison Act of 1914, as interpreted by the Supreme Court, completed the legislative process which had gradually transformed the drug addict from a patient into a criminal. 76 Initially it seemed that Britain would follow the same path. Regulation 40B of the Defence of the Realm Act (1916), and the Dangerous Drugs Act (1920) for the first time regulated the trade in narcotic drugs, and could easily have led to the full-scale criminalization of the issue of drug addiction.77

In 1924, in the wake of sensational journalistic allegations of widespread drugtaking in London and other large cities, the Minister of Health, acting in co-operation with the Home Office, appointed a committee to investigate the extent of narcotic drug addiction in the kingdom. Certainly the most striking feature about the committee was its composition. It was chaired by Sir Humphry Rolleston, and composed entirely of medical men. It included several physicians - Sir William Willcox, R. W. Branthwaite, and Professor W. E. Dixon - who had close ties to the SSI, and who had published papers on drug addiction. Thus British politicians and bureaucrats accepted that policy recommendations on drug addiction should be made solely by recognized medical experts. As if to confirm their judgment, the committee interviewed only medical men and those connected with the drug trade. (The only exception, among thirty-four witnesses, was Sir Archibald Bodkin, the Director of Public Prosecutions). ${ }^{78}$

The Rolleston committee's report, issued in 1926, defined an addict as "a person who, not requiring the continued use of a drug for the relief of the symptoms of organic disease, has aquired, as a result of repeated administration, an overpowering desire for its continuance, and in whom withdrawal of the drug leads to definite symptoms of mental or physical distress or disorder."79 According to the testimony of all witnesses, "in this country, addiction to morphine or heroin is rare", and "has diminished in recent years". 80 Under "Nature and causation", the report stated that addiction "must be regarded as a manifestation of disease, and not as a mere form of vicious indulgence. In other words, the drug is taken in such cases not for the purpose of obtaining positive pleasure, but in order to relieve a morbid and overpowering craving." 81

The report stressed that most addicts acquired their habits in the course of medical treatment, although "mental or nervous instability" is a predisposing factor. The "abrupt withdrawal" method of treatment, favoured by many American physicians, is fraught with danger, and may well lead to the patient's fatal collapse. Gradual withdrawal, tailored to the needs of the individual patient, is altogether safer and more effective. 82

\footnotetext{
76 David F. Musto, The American disease: origins of narcotic control. New Haven, Yale University Press, 1973.

77 Virginia Berridge, 'War conditions and narcotics control: the passing of the defense of the realm regulation 40B', J. Soc. Pol. , 1978, 7: 285-304. Virginia Berridge, 'Morality and medical science: concepts of narcotic addiction in Britain, 1820-1924', Ann Sci. , 1979, 36: 67-85.

78 Ministry of Health, Departmental committee on morphine and heroin addiction report, London, H.M.S.O., 1926, 'Appendix'.

78. Ibid., p. 9.

80 Ibid., p. 10.

81 Ibid., p. 11.

82 Ibid., pp. 14-15.
} 


\section{Terry M. Parssinen and Karen Kerner}

Prognosis for most addicts is not favourable: "Relapse, sooner or later, appears to be the rule, and permanent cure the exception. With two exceptions, the most optimistic observers did not claim a higher percentage of lasting cures than from 15 to 20 per cent." 83 The report recommended that two classes of persons should continue to be maintained on non-increasing doses of opiates: "Those in whom a complete withdrawal of morphine or heroin produces serious symptoms which cannot be treated satisfactorily under the ordinary conditions of private practice; and those who are capable of leading a fairly normal and useful life [sic] so long as they take a certain quantity, usually small, of their drug of addiction, but not otherwise." 84

Finally, the report insisted that medical men continue to have complete control over the prescribing and dispensing of narcotic drugs, subject only to the review of a medical tribunal composed of three medical men and a legal assessor. The report strenuously denied the need for further regulation which would impinge on the professional autonomy of medical men. While the committee did not challenge the right of the government to regulate the manufacture, trade, and retail sale of narcotic drugs, it strongly attacked the suggestion that the government regulate the physician's right to prescribe narcotic drugs freely. Clearly the Rolleston committee was prepared to recommend only those measures to deal with drug addiction which did not encroach on the professional prerogatives of medical men. Despite its limitations, the report, along with the Dangerous Drugs Acts of the early 1920s, remained the basis of British policy toward narcotic drugs until 1968.

The Rolleston committee report, then, was the culmination of the attempts to define drug addiction as a disease. The dispassionate, bureaucratic prose of the report is in distinct contrast to the outbursts of moral outrage that occasionally burst through the surface of earlier medical writings on the subject. By 1926, the medicalization of the "problem" of addiction was complete; it could be discussed by medical men like any other disease, without a moral quaver in their collective voice.

\section{WHY DID MEDICAL MEN DEFINE DRUG ADDICTION AS A DISEASE?}

If medical men had been aware that opium produced patient dependence, tolerance, and withdrawal as early as the eighteenth century, why was it not until the 1870s and 1880 s that they began to consider opium addiction a disease? The answer to this question is multi-layered.

First, and most important, subcutaneous injection made it possible for the patient to take a much larger dose of morphia than was usually taken in laudanum. An ounce of laudanum contained about one grain of morphia. Although some morphia addicts kept their daily dosage at five grains or less, ten to twelve grains was more common, and thirty, forty, or fifty grains per day was not unusual. While there were a few laudanum addicts - most notably Thomas DeQuincey - whose dosage was a pint or more of laudanum per day, these were very unusual. The more typical dose for a laudanum addict was one or two ounces, far below the usual quantity taken by a morphia addict. ${ }^{85}$ And, because the morphia was injected rather than ingested, less was

85 These figures are derived from our calculations of dosages of several hundred cases of habituation 


\section{Development of the disease model of drug addiction in Britain, 1870-1926}

lost in the process of absorption, and a higher proportion of the drug reached the central nervous system. Thus medical men were seeing, in morphia addicts, patients who were absorbing a much greater quantity of the drug than were opium addicts, and whose physiological complaints were therefore intensified.

Second, the concept of drug addiction - especially in its more rigid and moralistic formulation - was in part a reaction to the sanguine predictions about morphia in the 1850 s and 1860 s. A theme that runs through the drug addiction literature is that physicians were, and are guilty of creating drug dependence in their patients because of their incautious administration of morphia. One way to counter this trend is to warn physicians that, by using morphia, they risk creating a new disease even more dangerous than the disease they are trying to treat with it.

Third, physicians were appalled that they had lost control of this new therapy. Initially, hypodermic injections were administered only by physicians, often in a hospital or other institution. But syringes eventually passed into the hands of patients, their servants and relatives, since it was often not possible for a medical man to adminster every injection personally. Furthermore, there was no significant legal restriction on the sale of morphia until 1916. Medical prescriptions belonged to the patient, and could be refilled indefinitely. From the 1890 s, medical men lobbied for legislation to make prescriptions for narcotic drugs non-repeatable. It is possible to interpret this as a self-serving attempt by medical men to enhance their fees by making patients more dependent upon them. In part, it undoubtedly was. But from a different perspective, the same demand can be seen as a call for a preventative public health measure. If addiction is a disease, then it is essential to keep the infectious agent away from the potential victim to the greatest extent possible.

Fourth, the concept of addiction was shaped in part by the class of patients that physicians were seeing. Opium - in powder, pills, laudanum, or in patent or proprietary medicines - could be purchased over the counter at chemists' and other shops. In an age when the fees of medical men often placed their services out of reach of poor people, except in times of grave distress, opium was a cheap and effective form of self-medication. Many persons became opium habitués without ever seeing a physician, and without recognizing that they were sick. Morphia addiction, however, as a therapeutically-induced disease, was usually limited to the well-to-do because they were most likely to consult a physician when they were ill, and to be able to afford the cost of morphia and syringes. Finally, the cost of treatment for addiction could be very high. Dr. Oscar Jennings, for example, charged 200 guineas, payable in advance, for treatment in his retreat outside of Paris. ${ }^{86}$ Not surprisingly, then, medical writers spoke of drug addiction as a disease of "brain workers", or "the upper classes". Quite simply, those were the patients whom they saw.

So far we have limited our explanation for why medical men defined drug addiction as a disease to factors arising from the doctor's interaction with his patient. But there is another, less immediate level of causation, rooted in the changing role and status of the

reported in the medical press. For a fuller discussion of the issue, see our forthcoming book, 'Dope fiends and gentlewomen: opium and British society 1800-1926' (Institute for the Study of Human Issues, 1981).

86 G. Laughton Scott, The morphine habit and its painless treatment, London, H. K. Lewis, 1930 , p. 87. 


\section{Terry M. Parssinen and Karen Kerner}

medical profession in Victorian society. It is by now a commonplace among social historians that nineteenth-century medical men were appropriating certain functions previously exercized by priests. Physicians, the new guardians of morality, simply substituted new names for ancient evils: madness became mental illness; drunkenness became alcoholism; and the sin of Onan became masturbation. The old sins to be confronted and overcome were, by the late nineteenth century, diseases to be cured.

As late as the early nineteenth century, the very concept of disease was still illformed. Nineteenth-century medical men managed symptoms, not just because they could not cure diseases, but often because they had difficulty identifying them. While some diseases, especially acute, epidemic diseases, like smallpox, had been identified, and even treated effectively, others, especially endemic and chronic diseases, were often confused with the symptoms they produced. The old humoral theory of disease had been discredited in the eighteenth century, but nothing had replaced it. 87

Adding to the discomforts of medical men in the early nineteenth century was their organizational disarray. The tidy distinction among physicians, surgeons, and apothecaries was breaking down. The élitist medical establishment, centred in the Royal Colleges, was under severe attack from reformers like Thomas Wakley and his journal, the Lancet, and organizations of dissatisfied general practitioners, like the Provincial Medical and Surgical Association (later to become the British Medical Association). 88 On both theoretical and organizational levels, then, the medical profession in the early nineteenth century was weak and on the defensive.

By the late nineteenth century, however, the situation had changed considerably. From pioneering studies at the Paris hospital, and the work of Schwann and Virchow came the basis of a scientific, cellular pathology. The work of bacteriologists, most notably Koch and Pasteur, eventually gave the medical profession the germ theory of disease. ${ }^{99}$ While these accomplishments did not immediately lead to dramatic advances in therapeutics, they did give medical men a confidence that they could identify diseases and their causes with a precision previously unknown. The work of the reformers eventually produced the Medical Act of 1858 , which laid the basis for the legal

87 Erwin Ackerknecht, Therapeutics from the primitives to the twentieth century, New York, Hafner, 1973; Lester S. King, The medical world of the eighteenth century, Huntington, N.Y., Robert E. Krieger., 1971, (1st ed., University of Chicago Press, 1958); idem, 'Medical philosophy, 1836-1844', in Lloyd G. Stevenson and Robert P. Multhauf (editors), Medicine, science and culture, Baltimore, Md., Johns Hopkins University Press, 1968, pp. 143-159; and Gerald Geison, 'Social and institutional factors in the stagnancy of English physiology, 1840-1870', Bull. Hist. Med. 1972, 46: 30-58.

$88 \mathrm{M}$. Jeanne Peterson, The medical profession in mid-Victorian London, Berkeley, University of California Press, 1978, passim, esp. ch. I; Charles Newman, The evolution of medical education in the nineteenth century, London, Oxford University Press, 1957; W. J. Reader, Professional men: the rise of the professional classes in nineteenth century England, London, Weidenfield \& Nicolson, 1966; Noel Parry and José Parry, The rise of the medical profession: a study of collective mobility, London, Croom Helm, 1976; and Edwina C. Sherrington, 'Thomas Wakley and reform: 1832-62', unpublished D.Phil. thesis, University of Oxford, 1973.

89 Erwin Ackerknecht, Medicine at the Paris hospital, 1794-1848, Baltimore, Md., Johns Hopkins University Press, 1967; W. H. McMenemey, 'Cellular pathology, with special reference to influence of Virchow's teachings on medical thought and practice', in F. N. L. Poynter (editor), Medicine and science in the 1860s, London, Wellcome Inștitute for the History of Medicine, 1968, pp. 13-43; William Bulloch, The history of bacteriology, London, Oxford University Press, 1938, (reprinted 1960); Hubert A. Lechevalier and Morris Solotorovsky, Three centuries of microbiology, New York, McGraw-Hill, 1965; and J.K. Crellin, 'The dawn of the germ theory: particles, infection, and biology', in Poynter (editor), op. cit., pp. 57-76. 


\section{Development of the disease model of drug addiction in Britain, 1870-1926}

structure of the modern medical profession. And, as M. Jeanne Peterson has recently shown, medical men began to carve out a new autonomy for themselves by the power they wielded first in medical schools, and eventually in major teaching hospitals. 90 Finally, the public health movement achieved considerable legislative success in the 1860 s and 1870s, which vindicated an interventionist stance, and encouraged British medical men to extend the scope of public health concerns. ${ }^{91}$ By the $1880 \mathrm{~s}$, medical men were considerably more confident and aggressive than they had been just thirty years before. They believed that they could define disease with accuracy, and they were willing to push for legislation which they believed was necessary to control it. At this level of analysis, then, the definition of drug addiction as a disease was simply one of the smaller conquests made by the advancing medical army in the late nineteenth century.

More specifically, the attempt to define drug addiction as a disease was derived from, and secondary to, the more important attempt to define alcoholism as a disease. Unlike some German and American physicians, who saw drug addiction as a unique problem, to be discussed singularly, British physicians tended to see it as part of the much wider problem of "inebriety" or "narcomania". Indeed, drug addiction was often called "drug inebriety"; it was regularly subsumed in broader discussions, such as Richardson's Diseases of modern life, or Kerr's Inebriety or narcomania; and it occupied a decidedly secondary position in the concerns of the SSI. Even many of the most important sub-issues - inheritability, psychic as opposed to physiological causal factors, or compulsory confinement of addicts - were derived from the contemporary discussion on alcoholism. ${ }^{92}$ Not until the end of the first decade of the twentieth century did drug addiction clearly emerge in Britain as an entirely separate issue in both professional and popular literature.

\section{DRUG ADDICTION AND THE HISTORIOGRAPHY OF MEDICINE}

The dominant tradition in the historiography of medicine has been, and continues to be, progressivist and heroic; that is, it conceives of the history of medicine, at least in modern times, as a march of progress, led by the discoveries of selfless physicianscientists. Medical knowledge, in this tradition, is assumed to be objective, verifiable data about nature. Recently, this tradition has come under attack from different directions. Some social historians, in their studies of nineteenth-century medical men, have found them to be interested less in advancing medical knowledge than in their own status and income. M. Jeanne Peterson's fine study of mid-Victorian medical men in London portrays a medical élite raised to leading positions in the Royal Colleges, medical schools, and major hospitals not by superior knowledge, but by superior

90 Peterson, op. cit., note 88 above, passim.

91 William Frazer, A history of English public health, 1834-1939, London, Baillière, Tindall \& Cox, 1950, chs. 1-7; C. Fraser Brockington, Public health in the nineteenth century, Edinburgh, E. \& S. Livingstone, 1965; Jeanne L. Brand, Doctors and the state: the British medical profession and government action in public health, 1870-1912, Baltimore, Md., Johns Hopkins University Press, 1965; Roy M. Macleod, 'The anatomy of state medicine: concept and application', in Poynter (editor), op. cit., note 89 above, pp. 199-227.

92 William F. Bynum, 'Chronic alcoholism in the first half of the 19th century', Bull. Hist. Med. 1968, 42: 160-185; and Amy A. Pruitt, 'Approaches to alcoholism in mid-Victorian Britain', Clio Medica, 1974, 9; 93101. 


\section{Terry M. Parssinen and Karen Kerner}

connexions. Andrew Scull's examination of Victorian alienists depicts a group of "mad doctors" who struggled to grab and hold power in the burgeoning lunatic asylums in spite of their admitted inability to cure their patients. And Terry Parssinen's study of the conflict between mesmerists and medical men in the 1840s and 1850s shows that the latter were less interested in the efficacy than in the respectability of new therapies. 93

While these scholars have questioned the selfless motives of medical men, other scholars have cast doubt on the objectivity of their medical knowledge. Thomas Szasz argues that mental illness has no more foundation in nature than did heresy or witchcraft in the middle ages. Carol Smith-Rosenberg, along with other feminist historians, has interpreted the explosion of women's diseases in the nineteenth century as the result of the repressive social relations between Victorian men and women. Robert Neuman claims that the obsession of the nineteenth-century physician with the "disease" of masturbatory insanity resulted from his projecting "onto the masturbator many of his own repressed fantasies and guilt". And, in an article of truly breathtaking audacity, Karl Figlio argues that the nineteenth-century medical definition of chlorosis, a chronic disease of adolescence, must be seen as an ideological concept, originating in the relations of production of a capitalist society. 94 The thrust of this radical critique of traditional medical historiography cannot be adequately expressed in the distinctions between social as opposed to scientific medicine, and an "externalist" as opposed to an "internalist" perspective. The radicals are putting forward an alternative historiography, in which medical men are portrayed, not as disembodied intellects, but as social products of a specific culture, and in which medical knowledge is conceived as ideology in the service of an élite, with no more claim to objectivity than political or philosophical ideas.

This conflict between traditional and radical historiography of medicine recurs in the literature on the concept of drug addiction. Glenn Sonnedecker's article, 'Emergence of the concept of opiate addiction', is traditional in both form and content. After a brief review of medical writings on opium from ancient Egypt through the seventeenth century, Sonnedecker notes that Jones, Crumpe, and others pointed out phenomena related to opiate dependence, but "eighteenth century thought about the compulsive use of opiates smacked of descriptions of cabinet curiosities, and, in form, remained ill-defined if not confused. The lack of even an agreed-upon term suggests

\footnotetext{
93 Peterson, op. cit., note 88 above, Andrew Scull, Museums of madness: the social organisation of insanity in 19th century England, London, Allen Lane, 1979; and Terry M. Parssinen, 'Professional deviants and the history of medicine; mesmerists and medical men in Victorian Britain', in Roy Wallis (editor), On the margins of science: the social construction of rejected knowledge, Sociological Review monographs, University of Keele, 1979.

94 Thomas Szasz, The myth of mental illness, New York, Dell, 1961 ; idem, The manufacture of madness, New York, Harper \& Row, 1970; Carol Smith-Rosenberg, 'Puberty to menopause: the cycle of femininity in nineteenth century America', in M. Hartman and L. Banner (editors), Clio's consciousness raised, New York, Harper \& Row, 1974; idem, 'The hysterical woman: sex roles and role conflict in nineteenth century America', Social Research, 1972, 39: 652-678; C. Smith-Rosenberg and Charles Rosenberg, 'The female animal: medical and biological views of woman and her role in nineteenth century America', J. Am. Hist., 1973, 60: 332-356; Robert Neuman, 'The priests of the body and masturbatory insanity in the late nineteenth century', Psychohist. Rev., 1978, 4: 21-32; Karl Figlio, 'Chlorosis and chronic disease in nineteenth century Britain: the social constitution of somatic illness in a capitalist society', Social Hist. , 1978, 3: 167-197. See also idem, 'The historiography of scientific medicine: an invitation to the human sciences', Comp. Stud. Soc. and Hist., 1977, 19: 262-286.
} 


\section{Development of the disease model of drug addiction in Britain, 1870-1926}

that the idea remained amorphous, and the attention to it casual and unfocussed." 95 The hero of Sonnedecker's tale, predictably, is Edward Levinstein, whose book was enormously influential, he believes, "in placing the concept of addiction on concrete and common ground, and in raising informed medical discussion, henceforth, beyond the level of curious speculation and arm-chair moralizing."96 The nineteenth-century tendency to view addiction within a context of racialism and moralism were "complications" which detracted from a truly scientific understanding of the issue. He identifies, as a paradigm of this scientific understanding, the definition of drug addiction given by the World Health Organization's committee on addiction in 1955. Implicit in Sonnedecker's article is the assumption that addiction is, and was, a real disease, awaiting a discoverer. His task, as historian, is to trace the medical writings on the subject, and to hand out laurels or brickbats to their authors, depending upon their proximity to our present understanding.

Thomas Szasz offers us a rather different perspective. In a book published in 1974, he extends his radical critique of mental illness to the issue of drug addiction. The full title is an adumbration of his argument: Ceremonial chemistry: the ritual persecution of drugs, addicts, and pushers. Szasz comes directly to the point in the first paragraph: "In its present popular and professional use, the term 'addiction' refers not to a disease but to a despised kind of deviance. Hence the term 'addict' refers not to a bona fide patient but to a stigmatized identity, usually stamped on a person against his or her will. Addiction (or drug use) thus resembles mental illness and witchcraft, and the addict (or drug abuser) resembles the mental patient and witch, inasmuch as all of these names identify categories of deviance and their occupants." 97 Szasz denies that there is any pharmacological basis to addiction. The concept is better understood as part of the belief system of the quasi-religion of modern medicine: "Addictive drugs stand in the same sort of relation to ordinary or non-addictive drugs as holy water stands in relation to ordinary or non-holy water." 98 Szasz is difficult to resist. He has all the appeal of a modern Tom Paine indicting George III in the white coat of a physician. We have read Szasz and lost our innocence. About drug addiction, we no longer ask, with Sonnedecker, "How did medical men discover it?", but "Why did they create it?" Such a perspective can be enormously fruitful, as we hope that we have shown. It leads us to consider what effect social, cultural, and political factors may have had on the development of the concept of drug addiction.

Having admitted our indebtedness to Szasz, we want to put some distance between him and us. Using evidence as thin as workhouse gruel, Szasz presents a unidimensional explanation for why the concept of drug addiction developed as it did. ${ }^{99}$ Like mental illness, drug addiction was cut from whole cloth by psychiatrists who wished to extend their control over individuals' behaviour. Wielding the therapeutic ideology, psychiatrists created deviants ex nihilo. Given his penchant to see

95 Glenn Sonnedecker, 'Emergence of the concept of opiate addiction', J. mond. Pharm. , 1962, No. 3, pp. 275-290, 1963, No. 1, pp. 27-34; reprinted, Madison, Wis., American Institute for the History of Pharmacy, 1962-63, p. 16.

96 Ibid., p. 22.

97 Thomas Szasz, Ceremonial chemistry: the ritual persecution of drugs, addicts and pushers, London, Routledge \& Kegan Paul, 1974, p. xv.

98 Ibid., p. xvii.

99 Ibid., ch. 1. 
the history of medicine as a series of conspiracies, one could scarcely expect Szasz to draw any other conclusion.

It is here that we part company with Szasz. In spite of his importance as a corrective to Sonnedecker, his own explanation for the historical development of drug addiction is as slanted as Sonnedecker's, but in the opposite direction. The central weakness in his argument is his assertion that there is no pharmacological basis for addiction. Szasz apparently feels that he must deny the objective reality of addiction in order to strengthen his case for its being a malevolent social construct. But wishing does not make it so. In fact, opiates do produce unique physiological effects on their users.

As we have shown, for nearly two centuries before the 1870s, medical men had casually observed the addictive properties of opium. But in the widespread use of injected morphia, they were seeing patients whose dosages of the drug were so much greater than previously that it constituted an alarming new reality. While this is a necessary, it is not a sufficient explanation of why they should have translated this alarm into a disease model of drug addiction. That was, we have tried to argue, the result of factors which were derived from the "culture of medicine" in the late nineteenth and early twentieth centuries: the concept of disease, the social role and status of medical men, the perception of public health concerns, and the political goals and influence of medical men. The development of the disease model of drug addiction can only be understood, then, if we try to integrate the traditional and radical approaches to the history of medicine, by appreciating how socio-cultural factors mediated between medical men and the natural phenomena which they observed. 